\title{
Fashion designer selection with the method of GRA-based intuitionistic fuzzy multi-criteria decision making
}

DOI: $10.35530 / I T .070 .05 .1421$

\section{ABSTRACT - REZUMAT}

Fashion designer selection with the method of GRA-based intuitionistic fuzzy multi-criteria decision making

Personnel selection is a decision making problem based on the determination of the most suitable individual in line with the determined criteria, as known. Particularly in the labor-intensive sectors, such as apparel, the choice of the right personnel is a crucial problem and plays a key role in continuing the life cycle of companies successfully. In this study, the fashion designer selection process is examined for the design departments which are one of the most important organs for the apparel companies. For this purpose, the most suitable designer was chosen for an apparel company operating in Izmir province. In order to fulfill the aim, criteria weights which play an active role in designer selection are obtained through AHP method, and intuitive fuzzy logic sets are utilized to enable the evaluations of the candidates by the experts according to the criteria. In the light of these data, the final choice was conducted with the method of grey relational analysis.

Keywords: apparel sector, designer selection, multiple attribute decision making, GRA

\section{Selecția designerilor de modă pe baza metodei de luare a deciziilor multicriteriale fuzzy intuitive pe baza GRA}

Selecția personalului este o problemă de luare a deciziilor bazată pe identificarea celui mai potrivit individ, în conformitate cu criteriile determinate. În special, însectoarele cu program de lucru intensiv, precum confecționarea îmbrăcămintei, alegerea personalului potrivit este o problemă crucială și deține un rol cheie în continuarea cu succes a activității companiilor. În acest studiu, procesul de selecție a designerilor de modă este analizat pentru departamentele de proiectare, care reprezintă unele dintre cele mai importante departamente pentru companiile producătoare de îmbrăcăminte. În acest scop, a fost selecționat cel mai potrivit designer pentru o companie producătoare de îmbrăcăminte, care operează în provincia Izmir. Pentru a îndeplini obiectivul, ponderile criteriilor care joacă un rol activ în selecția designerilor sunt obținute prin metoda AHP, iar seturile cu logică fuzzy sunt utilizate pentru a permite evaluarea candidaților de către experți, în conformitate cu criteriile. Pe baza acestor date, selecția finală a fost realizată cu metoda de analiză și corelație gri.

Cuvinte-cheie: sectorul de îmbrăcăminte, selecția designerilor, luarea deciziilor multicriteriale, GRA

\section{INTRODUCTION}

Personnel selection arises as a decision making problem based on the selection of the most suitable individual for the work and organization among other candidates. The selection of the best and the most qualified employees is one of the crucial decisions in terms of the companies, since the knowledge, skills and abilities of these employees are the factors that directly affect the future of the company. Nowadays, companies face the developments in the technology and science and the growing intensity of the competition owing to the globalization. In this concept, it is observed that methods based on logic and mathematical background are increasingly widespread and put into practice, which is also valid for the personnel selection processes. Such methods allow a systematic reflection of the decision makers' opinions included in the selection problem, whereas enabling a more concrete and transparent selection process to be carried out from the candidate's point of view.

Looking at the literature, it appears that several techniques and different criteria are utilized in order to perform the analysis and the selection process of individuals from different sectors for different positions. The methods such as AHP, ANP, TOPSIS, fuzzy TOPSIS and fuzzy PROMETHEE seem to be frequently used by researchers in the studies based on the personnel selection [1-3]. One of these methods is the Grey Relational Analysis (GRA) and the Intuitionistic Fuzzy Sets (Fuzzy Sets) which are the subject of this study. For the selection of project manager for a technology firm and in another study, the selection process of the appropriate teaching personnel was analyzed with the help of GRA method [4-5]. Also, this method was applied to a technology company in the selection process of a software engineer [6]. In the study carried by Bali et al. [7], the selection process of a technology company was addressed through the Dephi technique and intuitionistic fuzzy sets. As shown in the literature, these methods are commonly used in personnel selection, but have been found to be limited in regard to the area of textiles and apparel. The common features of the aforementioned methods are that they are based 
on the Multiple Criteria Decision Analysis (MCDA) methods which are applied in the cases of several criteria affecting the result and they also allow the objective assessments. For this reason, it is considered that MCDA techniques can also be utilized in this field, textiles and apparel, as it is thought that the personnel selection processes in this area are performed under several criteria.

The apparel sector has a complicated structure with different dynamics. The growing competition, the increase in the expectations of customers, the constant increase in the number of the seasons and the variety of designs in order to adapt to the changing fashion trends, can be stated as the couple of reasons for this situation. Due to this structure of the sector, the personnel to be recruited must be selected among the individuals who have the qualifications to keep up with the companies' culture and have the ability of following the trends of the sector closely and adapting them. There are a number of studies available in the literature considering the personnel selection in the field of textiles and apparel. In another study [8], the techniques of survey, Delphi and BEI (Behavioral Event Interviewing) and proximity analysis were used in combination for the selection of the best personnel for the sales department in the textile sector. In another study, a survey was carried out with twenty-five different apparel enterprises located throughout Turkey and the researcher tried to reflect the personnel selection strategies of these companies [9]. Sener [10] ranked individuals for selecting blue-collar personnel for the production quality control in textile sector according to their suitability in the context of AHP method. In another study carried out in 2015, the selection of blue-collar personnel for sewing and quality control tasks to be employed in an apparel company was carried out through the AHP method [11].

In this study, the fashion designer selection process for the design department of an apparel company was investigated order to select the suitable personnel. One of the most important reasons for this selection is that the important position of the design department for having a direct affect in the customer profile and also the profitability of the company. The limited studies concerning the fashion designer selection in the apparel industry is noticed and therefore the study is thought to contribute to the literature in this respect. Within the scope of the study, Grey Relational Analysis is utilized which is one of the multi-criteria decision making methods including the evaluation process based on several criteria and verbal judgments and the most suitable designer for the company is determined among the other designer candidates.

\section{MATERIAL AND METHOD}

The study was carried out in consultation with the company of Spazio, operating in İzmir province. In 1980 , the company started its professional commercial activities by opening a ready to wear oriented boutique rather than bespoke tailoring which consists of the start-up stage of the company. In the 2000s, after the second generation-managers were included in the administration, the company has continued to have its presence under the brand name of Spazio. The company has been designing and producing in the area of women's daily wear, sportswear and night dresses. The company has eleven stores in total, including Aydın, Denizli and Izmit, provided that the majority of these stores are located in Izmir. As of 2016, the total number of personnel employed by the company is 60 , the annual production capacity is 100,000 pieces and the annual average turnover is 15 Million TL.

The company has been looking for a qualified designer who can contribute to the Spazio brand and also appeal to the customers' taste with the right designs. The method proposed in this study is based on the evaluations of the eligible candidates. Accordingly, the hierarchy consisting of the criteria in accordance with the criteria determined by the company experts that can be used in the selection of the designer is summarized in (figure 1).

Previous collection preparation experiences, mastery of the computer programs such as Photoshop and Adobe Illustrative which are related to design, having organization and management skills in order to be able to follow up the production of the designed products, following the developments in the area, possessing a research oriented character and having a vision and goals compatible with the company culture are the features expected from the designer candidates to be hired for the brand. The interviews were conducted and the decision problem was discussed within the framework of the following criteria with the Spazio chief designer who is also one of the second generation managers, as she is responsible for recruiting the designers.

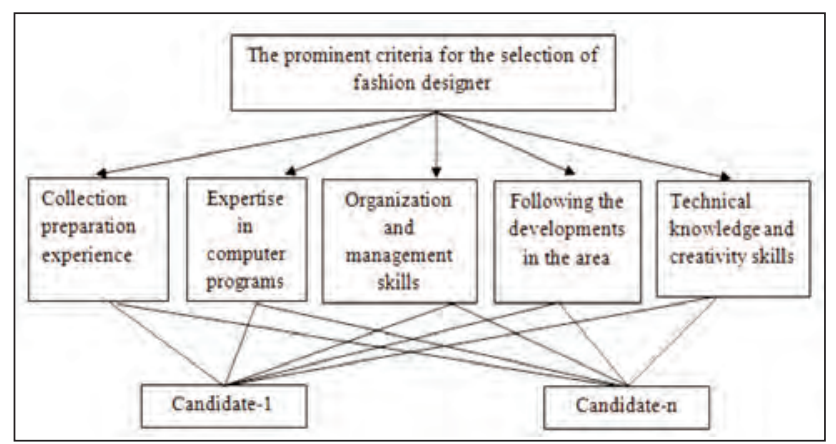

Fig. 1. Hierarchical structure consisting of the criteria considered in the selection of fashion designer for the company

In this study, the weights of the criteria which play an active role in choosing the designer to be recruited were determined by the AHP method, whereas the evaluations of the candidates were conducted by utilizing the intuitionistic fuzzy logic sets, according to the afore mentioned criteria. Finally, the final choice for this data was done through grey relational analysis method. 
The Fuzzy Set theory proposed by Zadeh attracted many researchers and it has been used in various fields. According to the fuzzy set theory, membership values of a set of elements can have values between 0 and 1 , and the sum of the membership and nonmembership degrees of an element is equal to 1 . However, the concept of fuzzy sets is extended to intuitionistic fuzzy sets by Atanassov [12]. In this concept, intuitionistic fuzzy set is characterized by a membership function, non-membership function and as well as a third function called the hesitation degree which enable to depict the data analyzed more comprehensively than fuzzy set which is only characterized by a membership function. Moreover, the grey relational analysis (GIA) method proposed by Deng [13] has been widely used in various multiple decision making problems. It has been proven to be useful in decision making under the circumstances including multiple factors [7]. The characteristics and the preliminaries of these theories are summarized as follows [14-15].

According to the concept of intuitionistic fuzzy sets, the set of the alternatives is expressed as $X=\left\{x_{1}, x_{2}\right.$, $\left.\ldots, x_{m}\right\}$, the discrete cluster showing the possible alternative set is defined as $i=1,2, \ldots, m$. The set of the criteria is expressed as $C=\left\{c_{1}, c_{2}, \ldots, c_{n}\right\}$, where $n$ defines a finite set indicating the number of relevant criteria. The vector of the criteria weights is expressed as $\omega=\left(\omega_{1}, \omega_{2}, \ldots, \omega_{n}\right)$, where $\omega_{j} \geq 0, j=1,2, \ldots, n$ and $\sum_{j=1}^{n} \omega_{j}=1$.

The functions of $\mu_{A}(x)$ and $v_{A}(x)$ denote, respectively, the degree of membership and the degree of nonmembership of the element $x \in X, A \subseteq X .(x)$ is called the degree of indeterminacy membership of the element $x \in X$ to the set $A$. It is assumed that this may arise from the information loss or personal errors. If the relation of these three forms is expressed in the following way, it becomes possible to mention the presence of an intuitionistic fuzzy set (1).

$$
\pi_{A}(x)=1-\mu_{A}(x)-v_{A}(x)
$$

According to the grey relational analysis concept, the original reference set is expressed as $x_{0}(j)$ and $x_{i}(j)$ is the value of $i$ th alternative with respect to $j$ th criterion, where $i=1,2, \ldots, m ; j=1,2, \ldots, n$ assuming that there are $m$ alternatives and $n$ criteria. The grey relational coefficient is computed via the following equation (2), here the distance between $x_{i}$ and $x_{0}$ is calculated through the following equation (3), which is also defined by other researchers as it is shown in (4).

$$
\begin{gathered}
\xi_{i j}=\frac{\delta_{\min }+\rho \delta_{\max }}{\delta_{i j}+\rho \delta_{\max }}, i \in M, j \subseteq N \\
\delta_{i j}=d\left(r_{i j}, r_{0 i}\right) \\
d\left(\alpha_{1}, \alpha_{2}\right)=\frac{1}{2}\left(\left|\mu_{\alpha 1}-\mu_{\alpha 2}\right|+\left|v_{\alpha 1}-v_{\alpha 2}\right|+\right. \\
\left.+\left|\pi_{\alpha 1}-\pi_{\alpha 2}\right|\right)
\end{gathered}
$$

$\rho$ is called as the distinguishing coefficient and usually taken as 0.5 by the decision makers in the literature as this value offers good stability and also good distinguishing effects. Finally, grey relational grade is determined to enable the comparisons between alternatives, which are calculated through (5). Here, $\omega_{j}$ indicates the weight of the $j$ th criterion.

$$
\gamma_{i}=\sum_{j=1}^{n} \omega_{j} \xi_{0 i}(j), \quad i \in M
$$

The application steps of the combination of these methods are indicated in the following steps.

Step 1: Alternatives, criteria and decision makers need to be defined. Subsequently, on the basis of the criteria, each decision maker needs to evaluate alternatives with the help of linguistic variables. If the problem requires, these evaluations can be repeated in a certain number of periods. The intuitionistic fuzzy set is constructed via the intuitionistic fuzzy values of the corresponding linguistic values. The elements forming this matrix are expressed as $r_{i j}=\left(\mu_{i j}, v_{i j}, \pi_{i j}\right)$.

The linguistic variables and their corresponding intuitionistic fuzzy values used in evaluating the alternatives in this study are summarized in the following table 1 [15-16].

Table 1

LINGUISTIC VARIABLES AND CORRESPONDING
INTUITIONISTIC FUZZY VALUES USED
IN THE EVALUATION OF CANDIDATES

\begin{tabular}{|c|c|}
\hline Linguistic variables & Intuitionistic fuzzy values \\
\hline Extreme high $(\mathrm{EH})$ & $(0.95,0.05,0.00)$ \\
\hline Very high $(\mathrm{VH})$ & $(0.85,0.10,0.05)$ \\
\hline High $(\mathrm{H})$ & $(0.75,0.15,0.10)$ \\
\hline Medium high $(\mathrm{MH})$ & $(0.65,0.25,0.10)$ \\
\hline Medium $(\mathrm{M})$ & $(0.50,0.40,0.10)$ \\
\hline Medium low $(\mathrm{ML})$ & $(0.35,0.55,0.10)$ \\
\hline Low $(\mathrm{L})$ & $(0.25,0.65,0.10)$ \\
\hline Very low $(\mathrm{VL})$ & $(0.15,0.80,0.05)$ \\
\hline Extreme low $(\mathrm{EL})$ & $(0.05,0.95,0.00)$ \\
\hline
\end{tabular}

Step 2: In this step, if it is thought that the importance of decision makers vary in the selection problem, the weight assignments are conducted for each of the decision makers.

Step 3: If the selection problem requires a group decision as stated in Step 2, then the aggregated intuitionistic fuzzy decision matrix is constructed based on the opinions of decision makers.

Step 4: Weights of the criteria need to be determined because of the reason that their importance and contributions to the solution of the problem may vary. In this step of this study, the method of AHP was used to determine the criteria weights. As it is known, the hierarchy of the problem needs to be established primarily within this method. Subsequently, the decision makers evaluate the criteria through the pairwise comparison matrices by means of a scale scoring between 1 and 9 . The general measurement scale of AHP consists of the following importance degrees and their relevant descriptions. 
"1: Equally important, 3: Weakly important, 5: Strongly important, 7: Very strongly important, 9: Extremely important, 2-4-6-8: Intermediate values". The consistency of the pair-wise comparison matrices must be tested in the course of determining whether the data are reliable by computing the consistency ratio (CR). If $\mathrm{CR} \leq 0.10$, it means that the consistence of the pair-wise comparison matrix is acceptable [17-18].

Step 5: The reference sequence needs to be determined in order to be able to make comparisons for the criteria. The reference sequence should be the optimal sequence of the criteria values. In the intuitionistic fuzzy decision matrix, the maximum value of $\alpha^{+}=(1,0,0)$ can be used as the reference value. Accordingly, the reference series $x_{0}$ is expressed as follows (6).

$$
x_{0}=\left(r_{0 j}\right)_{1 \times n}=\left[\alpha^{+} \alpha^{+} \alpha^{+} \ldots \alpha^{+}\right]
$$

Step 6: Grey relational coefficient should be determined. For this purpose (2) is utilized.

Step 7: Grey relational grades should be estimated via (5).

Step 8: In the last step alternatives are ranked according to the decreasing order of their grey relational grades and the greater the value of the grey relational grade, the better the alternative is, meaning that this alternative can be chosen as the most appropriate one.

\section{THE FINDINGS OF THE STUDY}

The afore-mentioned steps were followed in order to realize the designer selection.

Step 1: Accordingly, the recruiting specialist, who is primarily the decision maker, identified six alternative designer candidates. The set of alternatives is defined as $X=\left\{x_{1}, x_{2}, \ldots, x_{6}\right\}$ and the set of criteria is defined as $C=\{$ Collection preparation experience, Expertise in computer programs, Organization and management skills, Following the developments in the area, Technical knowledge and creativity skills\}. The human resource recruitment specialist evaluated the designer candidates through the linguistic variables specified in table 1 . The following tables show the evaluations of candidates with linguistic values and their corresponding fuzzy numbers (table 2 and table 3 ).

Steps 2 and 3: These steps have been skipped because the person who is in charge for the selection decision is the chief designer, rather than a group of people.

Step 4: In this step weights of the criteria used in the selection of the designer were determined with the help of AHP method. The criteria factor weights obtained as a result of pair-wise comparisons are listed in table 4 . The CR value obtained for all the matrices constructed in the study was 0.049 . It is possible to say that the data are valid because this

Table 2

\begin{tabular}{|l|c|c|c|c|c|}
\hline \multicolumn{6}{|c|}{ EVALUATION OF THE CANDIDATES WITH THE HELP OF THE LINGUISTIC VARIABLES } \\
\hline Criteria & $\begin{array}{c}\text { Collection } \\
\text { preparation } \\
\text { experience } \\
\left(C_{1}\right)\end{array}$ & $\begin{array}{c}\text { Expertise in } \\
\text { computer } \\
\text { programs } \\
\left(C_{2}\right)\end{array}$ & $\begin{array}{c}\text { Organization and } \\
\text { management } \\
\text { skills } \\
\left(C_{3}\right)\end{array}$ & $\begin{array}{c}\text { Following the } \\
\text { developments } \\
\text { in the area } \\
\left(C_{4}\right)\end{array}$ & $\begin{array}{c}\text { Technical } \\
\text { knowledge and } \\
\text { creativity skills } \\
\left(C_{5}\right)\end{array}$ \\
\hline Candidates $1\left(X_{1}\right)$ & $\mathrm{L}$ & $\mathrm{M}$ & $\mathrm{M}$ & $\mathrm{M}$ & $\mathrm{MH}$ \\
\hline Candidate $2\left(\mathrm{X}_{2}\right)$ & $\mathrm{L}$ & $\mathrm{MH}$ & $\mathrm{MH}$ & $\mathrm{MH}$ & $\mathrm{M}$ \\
\hline Candidate $3\left(\mathrm{X}_{3}\right)$ & $\mathrm{M}$ & $\mathrm{MH}$ & $\mathrm{M}$ & $\mathrm{M}$ & $\mathrm{MH}$ \\
\hline Candidate $4\left(\mathrm{X}_{4}\right)$ & $\mathrm{MH}$ & $\mathrm{MH}$ & $\mathrm{MH}$ & $\mathrm{MH}$ & $\mathrm{M}$ \\
\hline Candidate $5\left(\mathrm{X}_{5}\right)$ & $\mathrm{M}$ & $\mathrm{L}$ & $\mathrm{M}$ & $\mathrm{M}$ & $\mathrm{MH}$ \\
\hline Candidate $6\left(\mathrm{X}_{6}\right)$ & $\mathrm{M}$ & $\mathrm{MH}$ & $\mathrm{L}$ & $\mathrm{M}$ & $\mathrm{MH}$ \\
\hline
\end{tabular}

\begin{tabular}{|c|c|c|c|c|c|}
\hline \multicolumn{7}{|c|}{ INTUITIONISTIC FUZZY VALUES OF THE CORRESPONDING LINGUISTIC VALUES } \\
\hline Criteria & $\begin{array}{c}\text { Collection } \\
\text { preparation } \\
\text { experience }\end{array}$ & $\begin{array}{c}\text { Expertise in } \\
\text { computer } \\
\text { programs }\end{array}$ & $\begin{array}{c}\text { Organization and } \\
\text { management } \\
\text { skills }\end{array}$ & $\begin{array}{c}\text { Following the } \\
\text { developments } \\
\text { in the area }\end{array}$ & $\begin{array}{c}\text { Technical } \\
\text { knowledge and } \\
\text { creativity skills }\end{array}$ \\
\hline Candidates & $0.25,0.65,0.10$ & $0.50,0.40,0.10$ & $0.50,0.40,0.10$ & $0.50,0.40,0.10$ & $0.65,0.25,0.10$ \\
\hline Candidate 2 & $0.25,0.65,0.10$ & $0.65,0.25,0.10$ & $0.65,0.25,0.10$ & $0.65,0.25,0.10$ & $0.50,0.40,0.10$ \\
\hline Candidate 3 & $0.50,0.40,0.10$ & $0.65,0.25,0.10$ & $0.50,0.40,0.10$ & $0.50,0.40,0.10$ & $0.65,0.25,0.10$ \\
\hline Candidate 4 & $0.65,0.25,0.10$ & $0.65,0.25,0.10$ & $0.65,0.25,0.10$ & $0.65,0.25,0.10$ & $0.50,0.40,0.10$ \\
\hline Candidate 5 & $0.50,0.40,0.10$ & $0.25,0.65,0.10$ & $0.50,0.40,0.10$ & $0.50,0.40,0.10$ & $0.65,0.25,0.10$ \\
\hline Candidate 6 & $0.50,0.40,0.10$ & $0.65,0.25,0.10$ & $0.25,0.65,0.10$ & $0.50,0.40,0.10$ & $0.65,0.25,0.10$ \\
\hline
\end{tabular}


value is compatible with the reliability reference of the method, which is $\mathrm{CR}<0.10$.

Table 4

CRITERIA WEIGHTS OBTAINED THROUGH AHP

\begin{tabular}{|l|c|}
\hline \multicolumn{1}{|c|}{$\begin{array}{c}\text { Criteria used in the designer } \\
\text { selection }\end{array}$} & $\begin{array}{c}\text { Criteria } \\
\text { weights }\end{array}$ \\
\hline Technical knowledge and creativity skills & $\omega_{1}=0.276$ \\
\hline Collection preparation experience & $\omega_{2}=0.220$ \\
\hline Organization and management skills & $\omega_{3}=0.220$ \\
\hline Following the developments in the area & $\omega_{4}=0.212$ \\
\hline Expertise in computer programs & $\omega_{5}=0.072$ \\
\hline
\end{tabular}

Step 5: Since all candidates are ideally expected to have the maximum value for each criterion, the maximum value of $\alpha^{+}=(1,0,0)$ is accepted as the reference value in the intuitionistic fuzzy decision matrix. Therefore, the reference series of the problem can be indicated as: $x_{0}=\left(r_{0 j}\right)_{1 \times 5}=\left(\left(\mu_{0 j}, v_{0 j}, \pi_{0 j}\right)\right)_{1 \times 5}$ $=((1,0,0),(1,0,0), \ldots,(1,0,0))$.

Step 6: The distance compared to the reference series and the grey relational coefficients of the candidates are highlighted in the following table 5 .

Table 5

\begin{tabular}{|c|c|c|c|c|c|}
\hline \multicolumn{7}{|c|}{$\delta_{i j}$ VE $\zeta_{i j}$ VALUES OF THE CANDIDATES } \\
\hline$\delta_{i j}$ & $\mathbf{C}_{1}$ & $\mathbf{C}_{\mathbf{2}}$ & $\mathbf{C}_{\mathbf{3}}$ & $\mathbf{C}_{\mathbf{4}}$ & $\mathbf{C}_{5}$ \\
\hline$\delta_{1 j}$ & 0.75 & 0.5 & 0.5 & 0.5 & 0.35 \\
\hline$\delta_{2 j}$ & 0.75 & 0.35 & 0.35 & 0.35 & 0.5 \\
\hline$\delta_{3 j}$ & 0.5 & 0.35 & 0.5 & 0.5 & 0.35 \\
\hline$\delta_{4 j}$ & 0.35 & 0.35 & 0.35 & 0.35 & 0.5 \\
\hline$\delta_{5 j}$ & 0.5 & 0.75 & 0.5 & 0.5 & 0.35 \\
\hline$\delta_{6 j}$ & 0.5 & 0.35 & 0.75 & 0.5 & 0.35 \\
\hline$\delta_{\min }$ & & & 0.35 & & \\
\hline$\delta_{\max }$ & & & 0.75 & & \\
\hline$\xi_{i j}$ & $\mathbf{C}_{1}$ & $\mathbf{C}_{2}$ & $\mathbf{C}_{3}$ & $\mathbf{C}_{4}$ & $\mathbf{C}_{5}$ \\
\hline$\xi_{1 j}$ & 0.64 & 0.83 & 0.83 & 0.83 & 1 \\
\hline$\xi_{2 j}$ & 0.64 & 1 & 1 & 1 & 0.83 \\
\hline$\xi_{3 j}$ & 0.83 & 1 & 0.83 & 0.83 & 1 \\
\hline$\xi_{4 j}$ & 1 & 1 & 1 & 1 & 0.83 \\
\hline$\xi_{5 j}$ & 0.83 & 0.64 & 0.83 & 0.83 & 1 \\
\hline$\xi_{6 j}$ & 0.83 & 1 & 0.64 & 0.83 & 1 \\
\hline
\end{tabular}

Step 7: The grey relational grade values for the alternatives were determined using the weights obtained by the AHP method. The grey relational grades of the alternatives are as follows:

$$
\begin{aligned}
& \gamma_{1}=0.7898 ; \gamma_{2}=0.8884 ; \gamma_{3}=0.8796 ; \gamma_{4}=0.9878 \\
& \gamma_{5}=0.8004 ; \gamma_{6}=0.8378
\end{aligned}
$$

Step 8: All candidates are ranked according to their grey relational grades and the candidate with the highest score is determined to be the most suitable candidate for the company. According to the order stated below, the candidate number 4 (x4) is proven to be the most suitable candidate to be selected for the Spazio Company with regard to the determined criteria and method.

$$
\begin{aligned}
& \gamma_{4}>\gamma_{2}>\gamma_{3}>\gamma_{6}>\gamma_{5}>\gamma_{1} \\
& x_{4}>x_{2}>x_{3}>x_{6}>x_{5}>x_{1}
\end{aligned}
$$

\section{CONCLUSIONS, EVALUATION AND RECOMMENDATIONS}

Personnel selection is one of the important factors that directly influence the success of the companies. This choice is becoming more important especially in sectors such as apparel, where the intensity of labor stands in the forefront. The rapidly changing fashion sense in the apparel sector and the developing and differentiating consumer desires in this direction have led the design departments of the companies to be overhauled and managed with a more professional understanding. Considering these aspects, the selection of the fashion designers for apparel companies needs to be conducted with more scientific and objective methods, rather than conventional and intuitive methods.

In this study, the designer selection process of a local apparel company was analyzed. In this context, the most suitable designer candidate had been determined based on the interviews with the chief designer of the company who is also one of the second generation managers, as she is in charge for recruiting the designers. In this context, the criteria that play a role in the selection of designer were determined, in accordance with the activities and objectives of the company. The importance ratios of these criteria were determined via the method of AHP, in order to avoid inconsistency and misidentification of the ranking. The grey relational analysis method is commonly used in the literature to reveal the geometric similarities of the series compared with the reference series. The idea behind the grey relational analysis concept is that if an alternative has the highest grey relational grade between the reference sequence and itself, then the alternative becomes of the best choice for the solution. In this study, the grey relational analysis method was utilized in the selection of appropriate design department personnel on the basis of determined criteria.

The integrated usage of AHP and intuitionistic grey relational analysis methods has also been supported and proven by previous studies on being suitable and providing effective solutions to selection problems. Selection process studies to be carried out within this approach can be expanded to different departments and different sectors for the similar decision making problems, by enabling the contributions to the literature. 


\section{REFERENCES}

[1] Güngör, Z., Serhadlığlu, G., Kesen, S.E., A fuzzy AHP approach to personnel selection problem, In: Applied Soft Computing, 2009, 9, 641-646

[2] Dağdeviren, M., A hybrid multi-criteria decision-making model for personnel selection in manufacturing systems, In: Journal of Intelligent Manufacturing, 2010, 21, 451-460

[3] Vatansever, K., Oncel, M., An implementation of integrated multi-criteria decision making techniques for academic staff recruitment, In: Journal of Management, Marketing and Logistics, 2014, 1, 2, 111-126

[4] Zavadskas, E.K., Turskis, Z., Tamošaitiene, J., Marina, V., Multi criteria selection of project Managers by applying grey criteria, In: Technological and Economic Development of Economy, 2008, 14, 4, 462-477

[5] Mukhopadhyaya, D., Pramanik, S., Grey relational analysis based intuitionistic fuzzy multi-criteria group decision making approach for teacher selection in higher education, In: International Journal of Computer Applications, 2011, $34,21-29$

[6] Kundakcı, N., Personnel selection with grey relational analysis, In: Management Science Letters, 2016, 6, 351-360

[7] Bali, Ö., A dynamic multi criteria decision making model under uncertainities, In: Journal of the Faculty of Engineering and Architecture of Gazi University, 2014, 29, 1, 131-140

[8] Orhan, K., The personnel selection applications in Turkey and the formation of a personnel selection battery for textile sector, Ege University-Institute of Social Sciences, Doctoral Thesis, 2003

[9] Özlü, P., A research study on personal selection process in ready-to-wear sector, In: Tekstilve Konfeksiyon, 2006, 3, 200-205

[10] Şener, T., Analytical Hierarchy Process for the personnel selection problem: An implementation for the textile sector, Selçuk University-Institute of Social Sciences, Doctoral Thesis, 2011

[11] Kanat, S., Atılgan, T., Employee selection with Analytic Hierarchy Process in Clothing Sector: Turkish Case, In: International Conference on Engineering and Natural Sciences - ICENS 2015, 15-19 May 2015, Skopje Macedonia, 2015, 314-320

[12] Atanassov, K.T., Intuitionistic fuzzy sets, In: Fuzzy Sets and Systems, 1986, 20, 87-96

[13] Deng, J., Control problems of grey systems, In: Systems and Control Letters, 1982, 1, 5, 288-294

[14] Köse, E., Aplak, H.S., Kabak, M., An integrated approach based on grey system theory for personnel selection, In: Ege Academic Review, 2013, 13, 4, 461-471

[15] Mondal, K., Pramanik, S., Intuitionistic fuzzy multicriteria group decision-making approach to quality clay-brick selection problems based on grey relational analysis, In: Journal of Applied Quantitative Methods, 2014, 9, 2, 35-50, 2014

[16] Zhang, S., Liu, S., A GRA-based intuitionistic fuzzy multi-criteria group decision making method for personnel selection, In: Expert Systems with Applications, 2011, 38, 11401-11405

[17] Donegan, H., Dodd, F., McMaster, T., A new approach to AHP decision-making, In: The Statician, 1992, 41, 295-302

[18] Saaty, T.L., Decision making with the analytic hierarchy process, In: International Journal of Services Sciences, 2008, 1, 1, 83-98

\section{Authors:}

\section{Dr. PELIN OFLUOGLU KUCUK}

\section{Prof. Dr. TURAN ATILGAN}

Department of Textile Engineering, Engineering Faculty, Ege University, Bornova/lzmir, Turkey e-mail: pelin.ofluoglu@ege.edu.tr, turan.atilgan@ege.edu.tr

\section{Corresponding author:}

\section{PELIN OFLUOGLU KUCUK}

e-mail: pelinofluoglu@gmail.com 